\title{
Multiproxy provenance study of the Chivillas Formation: A record of the Middle Jurassic to Early Cretaceous geodynamic evolution of southeastern Mexico
}

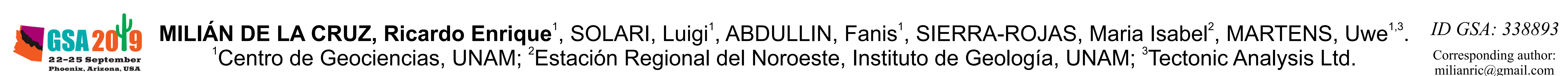
Corresponding author:
milianric@gmail.com

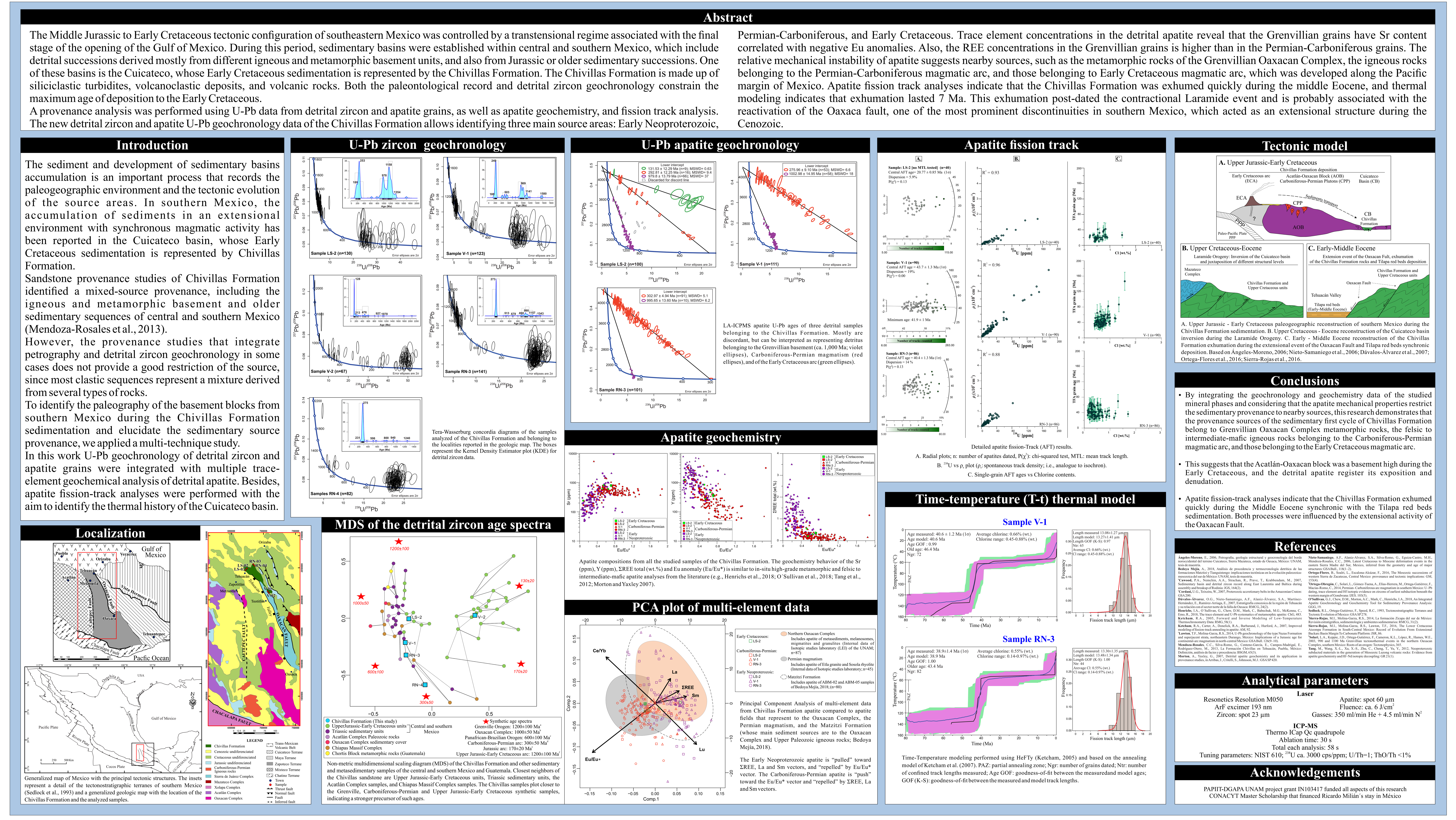

